\title{
Pengaruh Penerapan Pembelajaran Berorientasi Aktivitas Siswa Dan Motivasi Belajar Terhadap Prestasi Belajar Siswa Kelas IX SMP Negeri 3 Kabupaten Pamekasan
}

\section{Tiwuk Sutanti}

Email: tiwukpamekasan75@gmail.com

\begin{abstract}
Abstrak
This research related to Implementation of instruction based students' activities and Students' learning Motivation toward students' learning achievementt of Ninth Grade Students State Junior High School 3 Pamekasan regency. The students' learning achievementt is influenced by Implementation of instruction based students' activities. Additionally it is influenced by Students' learning Motivation. Good and regularly Implementation of instruction based students' activities brings a positive effect on the students' learning achievement and a high learning motivation in teaching will increase the students achievement.

The purpose of this research is (1) to describe Implementation of instruction based students' activities toward students' learning achievement. (2) to describe the significant influence of the Students' learning Motivation toward students' learning achievement . (3) to describe the significant influence of Implementation of instruction based students' activities and Students' learning Motivation simultaniously toward students' learning achievement.

The design of this research is descriptive quantitative. The subject of the research is Ninth Grade Students of State Junior High School 3 Pamekasan. The data collecting technique is by giving some questionnaires. Data analyzing technique used patial and multi-regression computerized SPSS 17.00 program for windows.

The Result and the discussion as follows: a) There is a significant influence on the Implementation of instruction based students' activities $\left(X_{1}\right)$ toward students' learning achievement is about 0,312. b) There is a significant influence on the Students' learning Motivation $\left(\mathrm{X}_{2}\right)$ toward students' learning achievement is about 0,062 by the significanct level 0,000, on t-account, that means smaller than 0,05. It can be concluded that X1 and X2 are very significant. c) There is a significant influence on the Implementation of instruction based students' activities and Students' learning Motivation simultaneously toward students' learning achievement is about 17,617 by the significanct level 0,000, on F-account, that means smaller than 0,05. It can be concluded that $X 1$ and $X 2$ are very significant toward $Y$.
\end{abstract}

Keyword: instruction based students' activities, motivation, achievement 


\section{PENDAHULUAN}

Proses pembelajaran IPS di sekolah selama ini lebih ditekankan kepada penguasaan materi sebanyak mungkin sehingga proses belajar bersifat kaku dan terpusat pada satu arah, tidak memberikan kesempatan bagi siswa untuk belajar lebih aktif dengan melakukan eksplorasi terhadap materi yang diajarkan. Kegiatan belajar lebih ditandai dengan budaya hafalan daripada berpikir, akibatnya siswa menganggap materi pelajaran IPS hanya untuk dihafalkan. Kenyataan ini menyebabkan siswa tidak mampu menerapkan konsep dasar dari materi IPS dalam kondisi kehidupan mereka.

Pembelajaran IPS di sekolah dipengaruhi oleh kebutuhan untuk memperoleh hasil evaluasi akhir yang memuaskan. Hal ini bukan saja berdampak pada perilaku siswa yang semata-mata mempelajari IPS dengan menghafal saja, tetapi juga pada metode pengajaran guru, kebijakan pimpinan sekolah, dan harapan orang tua terhadap hasil akhir yang dinilai secara kuantitatif saja. Dalam kondisi seperti ini strategi pembelajaran yang digunakan yaitu expository, biasanya hanya berupa ceramah yang berjalan satu arah (pendekatan teacher center) dan menekankan pada penguasaan materi sebanyak-banyaknya.

Untuk meningkatkan kualitas proses dan hasil belajar, para ahli pembelajaran telah menyarankan penggunaan paradigma konstruktivistik. Dengan perubahan paradigma belajar tersebut terjadi perubahan pusat (fokus) pembelajaran dari belajar berpusat pada guru kepada belajar berpusat pada siswa. Proses pembelajaran yang dilakukan harus interaktif, inspiratif, menyenangkan, menantang, memotivasi peserta didik untuk berpartisipasi aktif, serta memberikan ruang yang cukup tinggi bagi prakarsa, kreativitas dan kemandirian sesuai dengan bakat, minat dan perkembangan anak didik (PP 19/2005, pasal 19 ayat 1). Untuk mencapai tujuan tersebut guru hendaknya menerapkan model-model pembelajaran yang inovatif.

Berdasarkan hasil pengamatan peneliti pada saat pembelajaran menggunakan metode diskusi teman sebangku, sebagian besar siswa mengalami kesulitan menjawab soal yang diawali kata jelaskan, mengapa dan bagaimana (pertanyaan berbasis masalah), kegiatan diskusi teman sebangku siswa putri terlihat lebih aktif daripada siswa laki-laki, siswa cenderung pasif berdiskusi karena terbatasnya sumber belajar yang mereka miliki.

Kondisi pembelajaran IPS di Indonesia dewasa ini lebih diwarnai oleh pendekatan yang menekankan pada model pembelajaran konvensional yang lebih banyak diwarnai dengan ceramah, sehingga kurang mampu merangsan siswa untuk terlibat secara aktif dalam proses belajar mengajar (Suwarna, 2007: 146). Suasana belajar seperti ini semakin menjauhkan peran IPS dalam upaya mempersiapkan warga negara yang baik dan mampu bermasyarakat.

Pembelajaran IPS khususnya pada jenjang sekolah menengah pertama, masih menunjukan indikasi bahwa pola pembelajaran yang dikembangkan oleh guru 
cenderung bersifat guru sentris sehingga siswa hanya menjadi obyek pembelajaran. Kondisi pembelajaran seperti di atas jelas tidak mendorong pengembangan potensi diri siswa dalam pembelajaran, sehingga prestasi belajar yang dicapai oleh siswa juga tidak optimal, karena guru hanya mencekoki pikiran siswa dengan konsep-konsep materi pelajaran yang bersifat hafalan saja, kemudian dalam melakukan evaluasi juga hanya mengevaluasi materi yang diberikannya. Pembelajaran seperti itu nampaknya tidak mampu menunjang dan mendorong siswa untuk mengaktualisasikan potensi dirinya secara optimal. Suasaana belajar yang demikian mendorong lahirnya pola interaksi yang searah yaitu hanya dari guru ke siswa saja, sehingga akan mematikan kreativitas dan menghambat pengembangan potensi diri siswa.

Berdasarkan identifikasi permasalahan tersebut, diuji cobakan pembelajaran berorientasi aktivitas siswa. Untuk mengembangkan kemampuan yang dimiliki oleh siswa dalam mata pelajaran IPS melalui pembelajaran berorientasi aktivitas siswa dapat mengikuti pembelajaran menyenangkan dan kondusif serta prestasi belajar mata pelajaran IPS yang capai siswa akan optimal. Rumusan Masalah adalah sebagai berikut:

1. Apakah penerapan pembelajaran berorientasi aktivitas siswa mempunyai pengaruh yang signifikan terhadap prestasi belajar siswa kelas IX SMP Negeri 3 Pamekasan Kabupaten Pamekasan.

2. Apakah motivasi belajar mempunyai pengaruh yang signifikan terhadap prestasi belajar sisa kelas IX SMP Negeri 3 Pamekasan Kabupaten Pamekasan.

3. Secara bersama-sama apakah penerapan pembelajaran berorientasi aktivitas siswa dan motivasi belajar mempunyai pengaruh yang signifikan terhadap prestasi belajar siswa kelas IX SMP Negeri 3 Pamekasan Kabupaten Pamekasan.

\section{METODE PENELITIAN}

Jenis Penelitian Tindakan Kelas (Classroom Action Researh) ini menggunakan teknik purposive sampling atau sampel bertujuan yaitu mengambil subyek yang didasarkan atas tujuan tertentu (2006:39). Peneliti adalah guru dari sekolah tersebut, maka tujuan tertentu (purposive samplin) yaitu untuk memperbaiki proses dan hasil pembelajaran. Penelitian tindakan kelas ini menggunakan pola Hopkins dengan tiga siklus yang setiap siklus terdiri atas; (1) perencanaan, (2) tindakan dan pengamatan 
(observasi) dan (3) refleksi. Jika pada siklus ke dua telah tercapai ketuntasan belajar maka penelitian dianggap telah selesai.

Dalam mengumpulkan data, metode yang digunakan meliputi metode pengamatan (observasi), dokumentasi dan wawancara. Metode pengamatan digunakan untuk mengamati pembelajaran. Metode dokumentasi digunakan untuk mengumpulkan dokumen pembelajaran antara lain berupa RPP, naskah ulangan harian, tugas rumah, jurnal pembelajaran, daftar nilai, dan foto-foto kegiatan pembelajaran. Metode wawancara digunakan untuk mengetahui respon peserta didik berkaitan dengan penerapan model inquiry learning. Dalam melaksanakan metode pengamatan dan wawancara, peneliti dibantu seorang guru pendamping.

Penelitian ini menggunakan desain Kausal Korelasi Sejajar, karena penelitian ini untuk menentukan tingkat hubungan variabel - variabel yang berbeda dalam populasi ( Subana , 2005 : 36 ) Dilihat dari tingkat eksplanasi ini termasuk penelitian asosiatif, dengan bentuk variabel kasual ( Sugiyono, $2000: 6$ ). Penelitian asosiatif merupakan penelitian yang bertujuan untuk megetahui kasual antara dua variabel atau lebih ( Sugiyono, $2000: 11$ ) Tingkat eksplanasi dengan hubungan kasual serta jenis data kuantitatif akan dianalisa dengan regresi ganda menggunakan program SPSS versi 17.00 .

\section{Populasi dan Sampel}

Yang di maksud populasi adalah keseluruhan subjek yang akan dijadikan obyek penelitian. Menurut Arikunto (2008: 108). "Populasi adalah keseluruhan obyek penelitian”. Dalam penelitian ini populasi adalah seluruh siswa kelas IX SMP Negeri 3 Kabupaten Pamekasan TahunPelajaran 2015-2016 berjumlah 177 siswa, yang terdiri dari 5 kelas.

Prosedur pengambilan sampel menurut Arikunto, (2002:112) adalah sebagai berikut: "Jika subyek yang diteliti kurang dari 100 lebih baik diambil semua sebagai sampel, sehingga penelitiannya merupakan penelitian populasi. Selanjutnya jika jumlah subjek lebih dari 100 maka di ambil 10\%-15\% atau 20\%-25\% atau lebih". Berdasarkan pendapat diatas penulis berusaha mengambil sampel penelitian 25\%dari populasi berjumlah 177 siswa, sehingga sampel penelitian ini berjumlah 45 siswa. Agar setiap anggota populasi memperoleh hak yang sama untuk menjadi anggota sampel, maka prosedur pengambilan sampel dilakukakan dengan cara mengambil $25 \%$ dari jumlah 
siswa setiap kelas tekhnik proporsional randhom sampling. Berikut rincian siswa kelas IX SMP Negeri 3 Pamekasan

- Guna memperoleh data yang diharapkan yaitu data tentang penerapan pembelajaran berorientasi aktivitas siswa digunakan metode kuesioner atau angket, sedangkan untuk memperoleh data tentang motivasi beljar dan prestasi belajar menggunakan metode dokumentasi.

\section{Uji Hipotesis}

Di dalam pengujian hipotisis ini, uji penelitian dengan menggunakan dua variabel predictor, maka hipotesisnya menggunakan analisis regresi ganda dua predictor, dengan persamaan sebagai berikut: Untuk menguji hipotesis, pengaruh yang signifikan secara bersama-sama antara kedua variabel bebas, cara mengajar guru dan lingkungan keluarga terhadap variabel terikat prestasi belajar dilakukan dengan analisa regresi ganda dengan persamaan:

$\mathrm{Y}=\mathrm{a}+\mathrm{b} 1 \times 1+\mathrm{b} 2-\mathrm{X} 2$ (Sudjana; 2001; 163)

Keterangan :

$$
\begin{array}{lr}
\text { Y } & =\text { Prestasi Belajar } \\
\text { X1 } & =\text { Pembelajaran Berbasis Aktivitas Siswa } \\
\text { X2 } & =\text { Motivasi belajar } \\
\text { a } & =\text { Konstanta } \\
\text { b1,b2 } & =\text { Koefisien Regresi Parsial }
\end{array}
$$

\section{HASIL DAN PEMBAHASAN}

\section{Penerapan pembelajaran berorientasi aktivitas siswa (X1).}

Berdasarkan data instrumen penelitian yang diolah menggunakan Program SPSS Versi 18.00 pada lampiran 1 dengan jumlah item sebanyak 16 butir pertanyaan dan skor maximal per item 5 dari masing-masing item. Maka skor tertinggi variabel X1 adalah 18 x 5 = 80 dan hasil perhitungan tersebut, maka ditetapkan kelas interval untuk menetapkan frekuensi setiap kelas dan sekaligus dapat di tafsirkan criteria dari variabel X1. Bila dilakukan konversi berdasarkan skala lima, di peroleh data diperoleh data bahwa X1 menunjukkan kreteria sebesar 55,56\% termasuk kategori efektif, 31,11\% termasuk sangat efektif, dan $11,11 \%$ menyatakan sedang sedangkan 2,22\% yang 
menyatakan tidak efektif. Dapat disimpulkan bahwa penerapan pembelajaran berorientasi aktivitas siswa, menurut 45 Siswa kelas IX SMP Negeri 3 Pamekasan Kabupaten Pamekasan adalah efektif $(55,56 \%)$.

\section{Motivasi belajar (X2)}

Berdasarkan data lampiran 2, dari jumlah item 20 butir ,skor maksimal per item 5, maka skor tertinggi adalah 20 x $5=100$. Dari hasil perhitungan tersebut, maka ditetapkan kelas interval untuk menetapkan frekuensi masing-masing kelas dan sekaligus dapat ditafsirkan kreteria dari variabel X2 di peroleh data data bahwa X2 menunjukkan kreteria sebesar 48,89\% termasuk kategori kuat, 42,22\% termasuk kategori sangat kuat dan 6,67\% dalam kategori sedang, sementara 2,22\% masuk katagori tidak kuat. Dapat disimpulkan bahwa motivasi belajar, menurut 45 Siswa kelas IX SMP Negeri 3 Pamekasan Kabupaten Pamekasan adalah pada kategori kuat.

\section{Prestasi belajar siswa (Y)}

Berdasarkan data lampiran 3, dari jumlah 46 siswa skor maksimal perolehannya adalah 100 dari hasil perhitungan tersebut, maka ditetapkan kelas interval untuk menetapakan frekuensi masing-masing kelas dan sekaligus dapat ditafsirkan kriteria dari variabel $\mathrm{Y}$ di peroleh data data bahwa vareabel $\mathrm{Y}$ menunjukkan kriteria sebesar 51,11\% termasuk kategori tinggi dan 48,89\% kategori sangat tinggi Dapat disimpulkan bahwa prestasi belajar Siswa kelas IX SMP Negeri 3 Pamekasan Kabupaten Pamekasan sebanyak 46 siswa mempunyai Prestasi belajar yang tinggi.

\section{Pengujian Hipotesis Penelitian}

Proses pengujian hipotesis untuk setiap hipotesis penelitian yang di lakukan, semuanya didasarkan pada upaya untuk menjawab adanya hubungan antara variabel bebas dengan variabel terikat dengan menggunakan program SPSS 18 for windows

\section{Pengujian Hipotesis 1}

Terdapat pengaruh yang signifikan antara penerapan pembelajaran berorientasi aktivitas siswa terhadap prestasi belajar siswa kelas IX SMP Negeri 3 Pamekasan Kabupaten Pamekasan”. Koefisien korelasi variabel X1 terhadap Y (tabel 4.5) adalah 0,668 dengan probabilitas (p) $0,000<0,05$, menunjukkan variabel 
penerapan pembelajaran berorientasi aktivitas siswa (X1) dengan Prestasi belajar siswa kelas IX SMP Negeri 3 Pamekasan Kabupaten Pamekasan (Y) mempunyai tingkat pengaruh yang kuat dan sangat signifikan. Berikut adalah tabel hasil analisis korelasi vaiabel X1 X2 terhadap Y.

Untuk menguji taraf signifikan variabel penerapan pembelajaran berorientasi aktivitas siswa terhadap Prestasi belajar siswa kelas IX SMP Negeri 3 Pamekasan Kabupaten Pamekasan, di peroleh nilai t hitung sebesar 4,145 dan probabilitas $0,000<0,05$. maka Ho di tolak dan Hi di terima. dapat di simpulkan terdapat pengaruh yang signifikan antara penerapan pembelajaran berorientasi aktivitas siswa terhadap Prestasi belajar Siswa kelas IX SMP Negeri 3 Pamekasan Kabupaten Pamekasan di peroleh nilai konstanta $\alpha$ sebesar 57,458 dan koefisien standard $\alpha$ X1 sebesar 4,145, maka persamaan garis regresinya sebagai berikut : $\hat{\mathbf{Y}}=\mathbf{5 7 , 4 5 8}+\mathbf{0 , 3 1 2}$ $\mathbf{X 1}$ artinya setiap penambahan satu satuan nilai penerapan pembelajaran berorientasi aktivitas siswa (X1), akan terjadi peningkatan Prestasi belajar sebesar nilai koefisien regresi linier variabel penerapan pembelajaran berorientasi aktivitas siswa yaitu sebesar 0,312 poin setiap kenaikan 1 .

\section{Pengujian Hipotesis 2}

Hipotesis (Ho) dua berbunyi "tidak terdapat pengaruh yang signifikan antara motivasi belajar terhadap Prestasi belajar siswa kelas IX SMP Negeri 3 Pamekasan Kabupaten Pamekasan. Koefisien korelasi variabel X2 terhadap Y (tabel 4.6) adalah 0,484 dengan probabilitas (p) 0,000<0,05, menunjukkan variabel (X2) dengan Prestasi belajar siswa kelas IX SMP Negeri 3 Pamekasan Kabupaten Pamekasan (Y) mempunyai tingkat hubungan kuat dan sangat signifikan .

Untuk menguji taraf signifikan variabel motivasi belajar (X2) terhadap Prestasi belajar siswa kelas IX SMP Negeri 3 Pamekasan Kabupaten Pamekasan, di lakukan dengan uji regresi linier. Dari tabel 4.6 di peroleh nilai t hitung sebesar 0,884 dan probabilitas $0,000<0,05$. maka Ho di tolak dan Ha di terima. dapat di simpulkan terdapat pengaruh yang signifikan antara motivasi belajar terhadap Prestasi belajar Siswa kelas IX SMP Negeri 3 Pamekasan Kabupaten Pamekasan.

Dari tabel 4.6 di peroleh nilai konstanta $\alpha$ sebesar 57,458 dan koefisien standard $\alpha$ X2 sebesar 0,062 , maka persamaan garis regresinya sebagai berikut : $\hat{\mathbf{Y}}=$ 
$\mathbf{5 7 , 4 5 8}+\mathbf{0 , 0 6 2}$ X2 artinya setiap penambahan satu satuan nilai motivasi belajar (X2), akan terjadi peningkatan Prestasi belajar sebesar nilai koefisien regresi linier variabel motivasi belajar yaitu 0,62 .

\section{Pengujian Hipotesis 3}

Terdapat pengaruh yang signifikan antara penerapan pembelajaran berorientasi aktivitas siswa dan motivasi belajar terhadap prestasi belajar siswa kelas IX SMP Negeri 3 Pamekasan Kabupaten Pamekasan”. Dari hasil uji linier regresi linier ganda (tabel 4.7) di peroleh nilai $\mathrm{F}$ hitung sebesar 17,617 dan probabilias $0,000<0,05$, maka Ho di tolak dan Hi di terima. dapat di simpulakan terhadap pengaruh yang signifikan antara penerapan pembelajaran berorientasi aktivitas siswa dan motivasi belajar terhadap Prestasi belajar Siswa kelas IX SMP Negeri 3 Pamekasan Kabupaten Pamekasan di peroleh nilai konstanta $\alpha$ sebesar 57,,458 dan koefisien standard $\alpha$ X1 sebesar 0,312, $\alpha$ X2 sebesar 0,062 maka persamaan garis regresinya sebagai berikut : $\hat{\mathbf{Y}}$ $=\mathbf{5 7 , 4 5 8}+\mathbf{0 , 3 1 2} \times 1+\mathbf{0 , 0 6 2} \times 2$ artinya setiap penambahan satu satuan nilai penerapan pembelajaran berorientasi aktivitas siswa (X1) dan motivasi belajar (X2), terjadi peningkatan Prestasi belajar siswa kelas IX SMP Negeri 3 Pamekasan Kabupaten Pamekasan" sebesar nilai koefisien regresi linier masing-masing variabel bebas yaitu sebesar 0,312 dan 0,062.

Koefisien determinasi $\left(\mathrm{R}^{2}\right)$ di peroleh sebesar 0,456, artinya $+45,6 \%$ perubahan nilai Prestasi belajar siswa kelas IX SMP Negeri 3 Pamekasan Kabupaten Pamekasan disebabkan oleh perubahan yang terjadi pada penerapan pembelajaran berorientasi aktivitas siswa dan motivasi belajar sedangkan sisanya 54,4\% di sebabkan oleh variabel lain di luar penelitian ini besarnya sumbangan efektif masing-masing variabel yaitu: X1 terhadap Y sebesar 85\% dan untuk X2 terhadap Y sebesar 94\%.

\section{Pembahasan Hasil Penelitian}

Pengaruh penerapan pembelajaran berorientasi aktivitas siswa terhadap Prestasi belajar

Hasil uji hipotesis menunjukkan bahwa terdapat pengaruh yang signifikan antara penerapan pembelajaran berorientasi aktivitas siswa terhadap Prestasi belajar Siswa kelas IX SMP Negeri 3 Pamekasan Kabupaten Pamekasan. Hal ini dapat di tunjukkan dengan nilai t hitung sebesar 4,145 dan probabilitas $0,000<0,05$ sehingga 
Ho di tolak dan Hi di terima. dengan demikian untuk mencapai hasil yang memuaskan dalam Prestasi belajar, seorang guru harus melaksanakan penerapan pembelajaran berorientasi aktivitas siswa dengan baik.

Temuan tersebut mendukung teori bahwa salah satu perubahan dan perkembangan pendidikan adalah pendekatan pembelajaran sebagaimana pendapat Sanjaya, Pembelajaran berorientasi aktivitas siswa dapat di pandang sebagai suatu pendekatan dalam pembelajaran yang menekankan pada aktivitas siswa secara optimal untuk memperoleh hasil belajar berupa perpaduan antara aspek kognitif, afektif, dan psikomotorik secara seimbang (Wina Sanjaya, 2006:137)

Senada juga diungkapkan olehTrianto (2007:129) bahwa dalam kaitannya dengan belajar mengajar pemakaian istilah strategi atau model di maksudkan sebagai daya upaya guru untuk menciptakan suatu system lingkungan yang memungkinkan terjadinya proses belajar mengajar pengertian ini mengandung maksud bahwa penggunaan strategi/metode yang tepat dalam pembelajaran akan berdaya guna dan berhasil guna agar tercapai tujuan pembelajaran sesuai dengan rencana.

Pembelajaran berorientasi aktivitas siswa merupakan sistem pembelajaran yang menempatkan siswa sebagai subyek belajar. Dengan kata lain, "Pembelajaran di tekankan atau berorientasi pada aktivitas siswa" (Wina Sanjaya, 2006:135). Keaktifan siswa dalam proses pembelajaran diharapkan dapat merangsang dan mengembangkan bakat yang dimilikinya.

Pembelajaran berorientasi aktivitas siswa dapat di pandang sebagai suatu pendekatan dalam pembelajaran yang menekankan pada aktivitas siswa secara optimal untuk memperoleh hasil belajar berupa perpaduan antara aspek kognitif, afektif, dan psikomotorik secara seimbang (Wina Sanjaya, 2006:137)

Sedangkan tujuannya adalah untuk "meningkatkan kualitas pembelajaran agar lebih bermakna" (Wina Sanjaya, 2006:138), artinnya melalui PBAS siswa tidak hanya di tuntut untuk menguasai sejumlah informasi, tetapi juga bagaimana memanfatkan informasi itu untuk keduanya. Selanjutnya PBAS bertujuan mengembangkan seluruh potensi yang dimiliki siswa. Melalui PBAS siswa diharapkan dapat mengembangkan sikap, ketrampilan, dan kognitif semata.

\section{Pengaruh Motivasi belajar Terhadap Prestasi belajar}


Hasil uji hipotesis menunjukkan bahwa terdapat pengaruh yang signifikan motivasi belajar terhadap Prestasi belajar Siswa kelas IX SMP Negeri 3 Pamekasan Kabupaten Pamekasan. Hal ini di tunjukkan dengan nilai t hitung sebesar 0,884 dan probabilitas 0,381 < 0,05 sehingga Ho di tolak dan Hi di terima. dengan demikian untuk mencapai Prestasi belajar yang di harapkan maka seorang guru harus senantiasa memberikan arahan pada siswa untuk selalu menggunakan gaya dalam belajarnya malalui dorongan psikis yang ada dalam diri siswa ataupun di luar diri siswa.

Temuan tersebut mendukung pernyataan Sardiman (2010:75) bahwa motivasi belajar merupakan keseluruhan cara atau taktik di dalam diri siswa yang menimbulkan kegiatan belajar dan memberi arah pada kegiatan belajar, sehingga tujuan yang di kehendaki oleh subyek belajar dapat tercapai. Hal tersebut didukung oleh pendapat Martinis (2007: 219) juga berpendapat bahwa motivasi belajar merupakan daya penggerak psikis dari dalam diri seseorang untuk dapat melakukan kegiatan belajar dan menambah keterampilan, pengalaman. Senada dengan pendapat Agus Suprijono (2009: 163) menjelaskan motivasi belajar adalah proses yang memberi semangat belajar, arah, dan kegigihan perilaku. Artinya, perilaku yang termotivasi adalah perilaku yang penuh energi, terarah dan bertahan lama.

Mengingat demikian pentingnya peranan motivasi belajar bagi siswa dalam belajar, maka guru, orang tua siswa, keluarga dan siapapun yang terlibat dalam pendidikan siswa-siswanya di harapkan dapat membangkitkan dan meningkatkan motivasi belajar siswa. Agar siswa dapat mencapai prestasi belajar yang optimal, maka siswa harus memiliki motivasi belajar yang variatif. Dengan siswa yang tidak mempunyai gaya dalam belajarnya perlu dilakukan upaya-upaya semua pihak untuk memotivasi utamanya sebagai tenaga-tenaga pendidik.

\section{Pengaruh Penerapan pembelajaran berorientasi aktivitas siswa dan Motivasi belajar Terhadap Prestasi belajar}

Pada penelitian ini ditemukan bahwa Prestasi belajar siswa tentang penerapan pembelajaran berorientasi aktivitas siswa, motivasi belajar sescara bersamsama mempunyai pengaruh yang signifikan terhadap Prestasi belajar Siswa kelas IX SMP Negeri 3 Pamekasan Kabupaten Pamekasan. Hal ini di tunjukkan dengan nilai F hitung sebesar 17,616 dan probabilitas $0,000<$ F-tabel $(2,543)$ dengan tingkat signifikansinya 0,05 sehingga jika pemakaian penerapan pembelajaran berorientasi 
aktivitas siswa dilaksanakan dengan sebaik-baiknya dan tepat sasaran akan meningkatkan prestasi belajar siswa, sedangkan makin tinggi motivasi belajar siswa akan meningkatkan pula Prestasi belajarnya.

Diketahui pula bahwa sumbangan efektif penerapan pembelajaran berorientasi aktivitas siswa dan motivasi belajar secara bersam-sama terhadap Prestasi belajar adalah sebesar 0,456 (R-hitung) atau 45,6\% maka dapat di ketahui bahwa Prestasi belajar dapat diprediksi dari penerapan pembelajaran berorientasi aktivitas siswa dan motivasi belajar sebesar 06,2\% dari kedua variabel bebas tersebut motivasi belajar mempunyai sumbangan efektif relatif lebih rendah yaitu $24,8 \%$ di bandingkan dengan penerapan pembelajaran berorientasi aktivitas siswa dengan sumbangan efektif sebesar 31,2\%. Hal ini menunjukkan bahwa pengaruh penerapan pembelajaran berorientasi aktivitas siswa lebih dominan dibandingkan motivasi belajar.

Menurut Marpaung (2002) menegaskan bahwa dengan paradigma mengajar yang dipraktekkan dalam pembelajaran di sekolah, siswa tidak mendapat kesempatan untuk mengembangkan ide-ide kreatif, kemampuan berfikir strategis dan menemukan berbagai alternatif pemecahan masalah. Siswa menjadi sangat tergantung pada guru, tidak terbiasa melihat alternative lain yang mungkin dapat di pakai menyelesaikan suatu masalah secara efektif dan efisien. Akhirnya siswa menghafalkan saja semua rumus atau konsep tanpa memahami maknanya dan tidak mampu menerapkannya dalam berbagai situasi aplikatif. Disamping itu cara-cara tersebut diatas akan memudarkan dorongan bagi siswa untuk selalu mencari gaya-gaya yang sesuai dalam belajar.

Sedangkan yang tidak bisa diamati, seperti kegiatan mendengarkan dan menyimak (2006:141). Lebih lanjut dikemukan bahwa kadar pembelajaran berorientasi aktivitas siswa (PBAS) tidak hanya ditentukan oleh aktivitas fisik semata, akan tetapi juga ditentukan oleh aktivitas nonfisik seperti mental, intelektual dan emosional. Oleh sebab itu, sebetulnya aktif dan tidaknya siswa dalam belajar hanya siswa yang mengetahuinya secara pasti. Untuk mengetahui apakah suatu proses pembelajaran memiliki kadar PBAS yang tinggi, sedang, atau lemah, salah satunya dapat dilihat dari kriteria penerapan PBAS dalam proses pembelajaran. Kriteria tersebut menggambarkan sejauhmana keterlibatan siswa dalam pembelajaran baik dalam perencanaan pembelajaran, proses pembelajaran maupun dalam mengevaluasi hasil pembelajaran. Sementara Oemar Hamalik (2004: 175) menjelaskan fungsi motivasi antara lain: 
mendorong timbulnya kelakuan atau sesuatu perbuatan. Perbuatan akan terjadi apabila seseorang tersebut memiliki motivasi, sebagai pengarah, artinya dapat menjadi jalan agar mampu menuju arah yag ingin dicapai, sebagai penggerak, berfungsi sebagai mesin bagi mobil. Besar kecilnya motivasi akan menentuka cepat atau lambatnya suatu pekerjaan.

\section{KESIMPULAN}

Didasarkan pada hasil penelitian yang telah dilakukan dan telah digambarkan, maka dapat di simpulkan sebagai berikut:

1. Penerapan pembelajaran berorientasi aktivitas siswa memberi pengaruh yang signifikan terhadap Prestasi belajar siswa kelas IX SMP Negeri 3 Pamekasan Kabupaten Pamekasan.

2. Motivasi belajar memberi pengaruh yang signifikan terhadap Prestasi belajar siswa kelas IX SMP Negeri 3 Pamekasan Kabupaten Pamekasan.

3. Penerapan pembelajaran berorientasi aktivitas siswa dan motivasi belajar dalam pembelajaran secara bersama-sama memberi pengaruh yang signifikan terhadap Prestasi belajar siswa kelas IX SMP Negeri 3 Pamekasan Kabupaten Pamekasan.

\section{Saran-Saran}

Dari hasil penelitian ini memberikan beberapa saran yang perlu di perhatikan adalah sebagai beriut:

1. Guru hendaknya lebik kreatif dan inovatif serta akomodatif dalam memilih suatu bentuk atau model pembelajaran yang sesuai dangan materi ajar yang akan di sampaikan dalam proses belajar mengajar di depan kelas dengan tetap mengacu pada proses pembelajaran aktif dalam hal ini adalah Penerapan pembelajaran berorientasi aktivitas siswa. Karena Penerapan pembelajaran berorientasi aktivitas siswa benar-benar berpengaruh secara signifikan.

2. Untuk meningkatkan dorongan belajar, maka guru harus menganalisa dan memeberikan penggunaan media pembelajaran dalam belajarnya melalui dorongan psikis baik yang ada dalam diri siswa (internal) maupun yang ada di luar diri siswa (eksternal).

3. Demi pencapaian yang optimal di harapkan peran serta kepala sekolah. Guru , siswa dan orang tua siswa serta masyarakat untuk secara bersam-sama 
menentukan alternatif-alternatif atau solusi yang tepat dalam mengatasi kesulitan-kesulitan belajar siswa dengan tetap mengedepankan teknik-teknik atau penggunaan media pembelajaran yang tepat serta selalu menstimulus akan terjadinya penggunaan media pembelajaran demi pencapaian tujuan bersama.

4. Peneliti lain agar memperdalam judul penelitian ini atau pada faktor yang lain yang dapat meningkatkan Hasil Belajar Siswa yang berhubngan dengan strategi mengajar maupun belajar. Juga pada aspek yang lain yang berhungan dengan penggunaan media pembelajaran.

\section{DAFTAR PUSTAKA}

Anggoro, 2008. Metodelogi Penelitian Kualitatif. Jakarta: PT. Raja Grafindo Persada. Arikunto, 2002. Motivasi Belajar Untuk Meningkatkan Hasil Belajar. Jakarta: Balai Pustaka

Arikunto, Suharsini, 2002. Prosedur Penelitian. Jakarta: PT. Rineka Cipta.

BSNP, 2011. Standar Kompetensi Dan Kompetensi Dasar Sekolah Menengahn Pertama/MTs. Jakarta: Kemendiknas

Brown, BJ, 1971. Educational Sociologi, $(3$ nd, ed). New Jersey Particel hall Inc.

Djamarah, Syaiful B, 2000. Prestasi Belajar Dan Kompetensi Guru. Surabaya. Usaha Nasional.

Gitosudarmo, 1987. Interaksi Dan Motivasi Belajar. Jakarta: PT. Raja Grafindo Persada.

Hadi, Sutrisno, 1985. Statistik I. Yogyakarta, Andy Offset

Margono S. 2000. Metodologi Penelitian Pendidikan. Jakarta: Rineka Cipta

Poerwanto M, Ngalim, 1988. Prinsip-prinsip Dan Teknik Evaluasi Pengajaran, Bandung: Remaja Karya

Rakajoni T, 1993. Cara Belajar Siswa Aktif Wawasan Kependidikan Dan Pembaharuan Pendidikan Guru, Pidato Pengukuhan Guru Besar IKIP Malang.

Sanjaya, Wina, 2007. Strategi Pembelajaran (Berorientasi Standar Proses Pendidikan). Jakarta: Premanda Media Group.

---------, 2008. Strategi Pembelajaran (Berorientasi Standar Proses Pendidikan). Jakarta: Premanda Media Group

Sapria, 2009. Pendidikan IPS Konsep Dan Pembelajaran. Bandung: PT. Remaja Rosdahkarya Offset

Sudjana, Nana, 2000. Penilaian Hasil Belajar IPS. Bandung: PT. Remaja Rosdahkarya

Sapriya, 2009. Pendidikan IPS Konsep Dan Pembelajaran. Bandung: PT. Remaja Rosdahkarya Offset

Sugiyono, 2011. Metode Penelitian Pendidikan. Bandung: Alfabeta

Suryosubroto, B. 2009. Proses Belajar Mengajar di Sekolah. Jakarta: PT. Rineka Cipta

Syah, Muhibbin, 2002. Psikologi Pendidikan. Bandung: PT. Remaja Rosdakarya

Uno, Hamzah B. 2008. Model Pembelajaran. Jakarta: Bumi Aksara 
86

Yulianto, dkk (2008). Model-Model Pembelajaran Inovatif. Pusat Penerbitan Universitas Negeri Surabaya

http://akhmadsudrajat.wordpress.com/2011/01/30/pembelajaran-inkuiri-sosial/ diakses 2 Januari 2015) 